\title{
Mechanism of Distortion of Precious Alloy Restoration at High Temperatures
}

\section{(Part 2) Effect of Addition of Fe, In and Sn on the Deflection at High Temperatures}

\author{
Nobuo ANDO and Masahiko NAKAYAMA \\ Department of Dental Materials Science, Nippon Dental University, 9-20, Fujimi 1-chome, Chiyoda-ku, \\ Tokyo 102, Japan
}

Received on September 30, 1985

Iron, indium and/or tin were added to two mother alloys, 90Au-10Pd and $80 \mathrm{Au}-20 \mathrm{Pt}$, and $10 \mathrm{kinds}$ of alloys were prepared from each mother alloy. The total amount of the additional elements was 0.75 $\mathrm{wt} \%$. The deflection at high temperatures (the final deflection after the specimen was heated until $1050^{\circ} \mathrm{C}$ ) and the deflection-beginning temperature (the temperature at which $20 \mu \mathrm{m}$ deflection occurred) were measured, and the effect of the additional elements on these two properties was examined.

The deflection decreased by addition of Fe, In and/or $\mathrm{Sn}$ in both alloy system. The deflection-beginning temperature increased by addition of the elements. These results showed that the mechanical properties at high temperatures were improved by addition of $\mathrm{Fe}$, In and/or $\mathrm{Sn}$. The deflection at high temperatures and the deflection-beginning temperature were negatively correlated. Indium appears to increase the deflection in both alloy systems.

Key words: Deflection, Additional elements, PFM alloys

\section{INTRODUCTION}

The distortion of the cast core during the firing process is sometimes caused by the weight of the cast itself, especially at high temperatures ${ }^{1-5)}$. This phenomenon, called sag, was measured for the Au-Pt-Pd alloy system in the previous study ${ }^{6}$, and the sag behavior was found to be a good index to evaluate the alloys for porcelain fusing. In the previous study, nine kinds of Au-Pt-Pd alloys were prepared and the deflection and the deflectionbeginning temperature were determined.

A small amount of some metals are added to commercial gold alloys for porcelain fusing to increase the mechanical and/or bonding strength. Iron, indium and tin are mainly used as the additional elements in gold alloys for porcelain fusing. The effect of these elements on the bonding strength ${ }^{7)}$ and the thermal expansion coefficients ${ }^{8)}$ was examined in detail. The effect of these elements on the deformation of a casting core was examined by the measurement of the thermal expansion hysteresis ${ }^{9)}$. It was concluded that an increase of indium content or decrease of tin content increased the thermal expansion hysteresis and that iron was not effective for the hysteresis. A large thermal expansion hysteresis results in a large deformation of the casting.

It is interesting to examine the effect of addition of these elements on the sag behavior. Among nine Au-Pt-Pd alloys used in the previous study, two alloys, 90Au-10Pd alloy and $80 \mathrm{Au}-20 \mathrm{Pt}$ alloy, are binary. The other seven alloys are ternary, and they have inter- 
mediate compositions between the two binary compositions. To examine the effect of the additional elements on the deflection at high temperatures, it would be better to add these elements to the binary alloys rather than to the ternary alloys. Fortunately, the $90 \mathrm{Au}-10 \mathrm{Pd}$ alloy showed the minimum deflection at high temperatures, and the $80 \mathrm{Au}-$ $20 \mathrm{Pt}$ alloy showed the maximum one. In this study, these two alloys were selected as the mother alloys, and iron, indium and/or tin were added to these two binary alloys. The sag behavior was examined, and the effect of Fe, In and $\mathrm{Sn}$ on the deflection at high temperatures and the deflection-beginning temperature were observed.

\section{MATERIALS AND METHODS}

Two kinds of alloys, 90Au-10Pd and $80 \mathrm{Au}-20 \mathrm{Pt}$, were used as the mother alloys. Iron, indium and/or tin were added to each mother alloy, and $10 \mathrm{kinds}$ of alloys were prepared as shown in Fig. 1. The total amount of additional elements was $0.75 \%$. Each mother alloy was rolled to about $0.3 \mathrm{~mm}$ thickness and was divided into 10 parts. Powdered iron, indium and/or tin were weighed and they were wrapped by the rolled mother alloy. They were forged and melted in fused quartz tube by induction furnace in argon gas atmosphere. After melting, each alloy was kept at $1350^{\circ} \mathrm{C}$ for 20 minutes for homogenization and was quenched in water. Each alloy was rolled and cut into small pieces for the convenience of casting. The specimens for the measurement of the deflection were cast by the same method as described in Part 1. The size of the specimens was $32 \mathrm{~mm} \times 5 \mathrm{~mm} \times 0.5 \mathrm{~mm}$. They were heated at $1050^{\circ} \mathrm{C}$ for 10 minutes for homogenization. The same instrument was used for the deflection measurement as described in Part 1. The method to determine the deflection-beginning temperature was changed in this study, because some chart papers that showed very small deflection made it difficult to determine the linear portion for extrapolation. Instead the temperature at which the deflection became $20 \mu \mathrm{m}$ was defined as the deflection-beginning temperature.

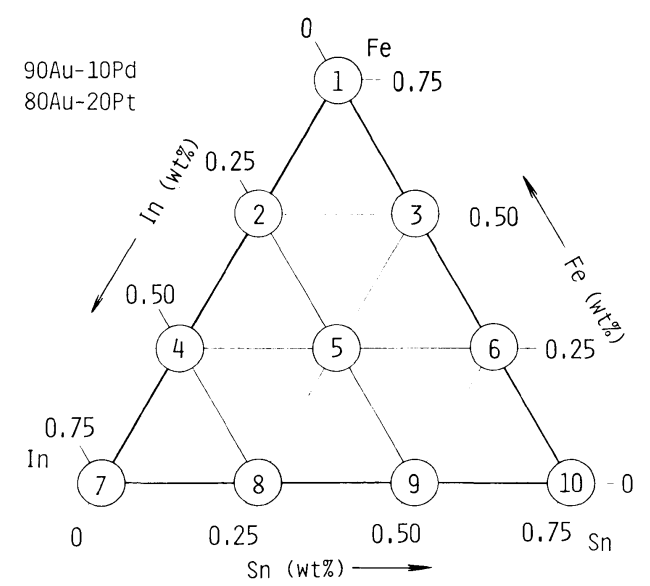

Figure 1 Composition arrangement of additional elements. Compositions of the mother alloys are 90Au-10Pd and 80Au-20Pt. 


\section{RESULTS}

The results of the deflection at high temperatures and the deflection-beginning temperature are shown in Table 1. The mean values are plotted in Fig. 2 (a) and (b). The

Table 1 The Deflection and the Deflection-Beginning Temperature

\begin{tabular}{|c|c|c|c|c|c|c|c|c|c|c|c|}
\hline \multirow{2}{*}{$\begin{array}{c}\text { Alloy } \\
\text { No. } \\
1\end{array}$} & \multicolumn{3}{|c|}{ Additional Elements } & \multicolumn{4}{|c|}{$\begin{array}{l}\text { 90Au-10Pd Alloy System } \\
\begin{array}{cc}\text { Deflection } & \text { Temperature } \\
(\mu \mathrm{m}) & \left({ }^{\circ} \mathrm{C}\right)\end{array}\end{array}$} & \multicolumn{4}{|c|}{$\begin{array}{l}\text { 80Au-20Pt Alloy System } \\
\begin{array}{cc}\text { Deflection } & \text { Temperature } \\
(\mu \mathrm{m}) & \left({ }^{\circ} \mathrm{C}\right)\end{array}\end{array}$} \\
\hline & 0 & 0 & 0.75 & 184 & 175 & 809 & 823 & 540 & 560 & 715 & 674 \\
\hline 2 & 0.25 & 0 & 0.50 & 191 & 232 & 824 & 813 & 630 & 592 & 733 & 717 \\
\hline 3 & 0 & 0.25 & 0.50 & 134 & 196 & 903 & 833 & 549 & 542 & 713 & 726 \\
\hline 4 & 0.50 & 0 & 0.25 & 152 & 281 & 876 & 829 & 548 & 575 & 794 & 760 \\
\hline 5 & 0.25 & 0.25 & 0.25 & 204 & 234 & 824 & 834 & 549 & 600 & 675 & 679 \\
\hline 6 & 0 & 0.50 & 0.25 & 140 & 180 & 894 & 815 & 524 & 534 & 699 & 735 \\
\hline 7 & 0.75 & 0 & 0 & 220 & 262 & 812 & 778 & 600 & 531 & 688 & 712 \\
\hline 8 & 0.50 & 0.25 & 0 & 178 & 188 & 859 & 877 & 452 & 521 & 763 & 755 \\
\hline 9 & 0.25 & 0.50 & 0 & 144 & 208 & 821 & 819 & 430 & 448 & 798 & 807 \\
\hline 10 & 0 & 0.75 & 0 & 168 & 209 & 824 & 817 & 508 & 580 & 755 & 729 \\
\hline
\end{tabular}

(a)

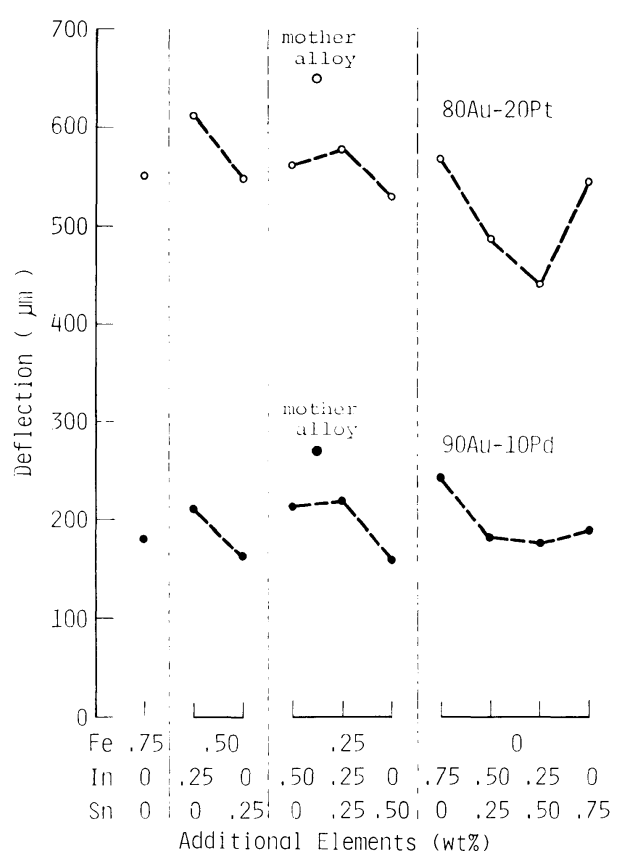

(b)

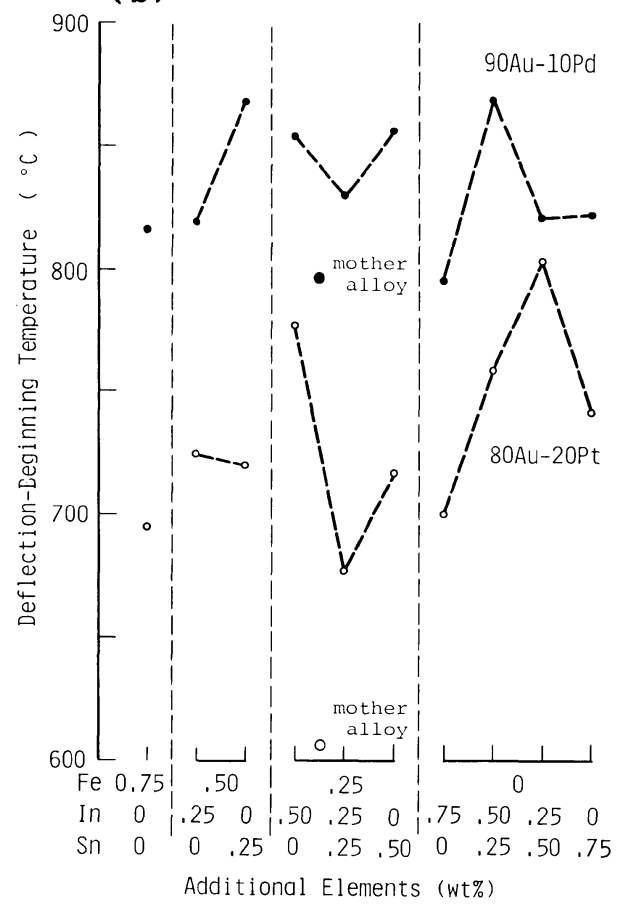

Figure 2 Concentration dependence.

(a) Deflection at high temperatures

(b) Deflection-beginning temperature 
$90 \mathrm{Au}-10 \mathrm{Pd}$ alloy system showed lower deflection than the $80 \mathrm{Au}-20 \mathrm{Pt}$ alloy system. On the other hand, the deflection-beginning temperature of the 90Au-10Pd alloy system was higher than that of the $80 \mathrm{Au}-20 \mathrm{Pt}$ alloy system. When the data were plotted in the order of the alloy number shown in Fig. 1, they could be grouped by iron concentration. In each group, the effect of the contents of additional elements was very complex in both (a) and (b). However, both alloys, 90Au-10Pd and 80Au-20Pt, showed the same concentration dependence in both alloy systems. The alloy that deflected larger showed the lower deflection-beginning temperature. The values of the mother alloys, which were redefined from the chart paper according to the new method described in the previous section, are also shown in the same figure. The deflection at high temperatures became smaller and the deflection-beginning temperature higher by addition of the elements in both alloy systems.

To understand the effect of the additional elements, equi-deflection contours and equi-deflection-beginning temperature contours were examined (Figs. 3 and 4). In the 90Au-10Pd alloy system, the effect of indium content appeared to be strong. The mean maximum value, $241 \mu \mathrm{m}$, was obtained in $0.75 \mathrm{In}$ vertex (No. 7). The minimum value was observed in two area, $0 \%$ In and $0 \%$ Fe sides of the triangle. The $80 \mathrm{Au}-20 \mathrm{Pt}$ alloy system showed different contour patterns. Both maximum and minimum values were obtained in the alloys that contain $0.25 \%$ indium. Iron appeared more effective than indium in this case.

The equi-deflection-beginning temperature contours of both alloy systems were very complex. The 90Au-10Pd alloy system had two areas of the maximum temperature. The $80 \mathrm{Au}-20 \mathrm{Pt}$ alloy system had two areas of the minimum temperature. No. 7 alloy, 0.75In, showed minimum or very low deflection -beginning temperature.

In both alloy systems, the relationship between the deflection and the deflection-beginning temperature was examined (Fig. 5). Both alloy systems showed a negative linear correlation. This means that the alloy that showed the larger deflection began to deflect
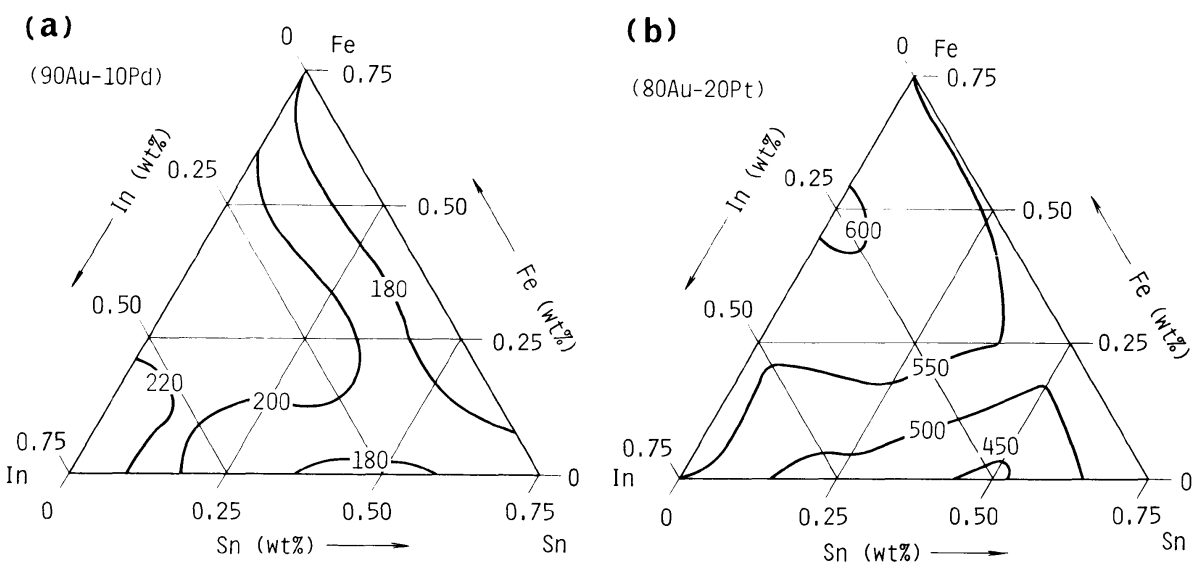

Figure 3 Equi-deflection contours $(\mu \mathrm{m})$ drawn on the composition arrangement chart.

(a) 90Au-10Pd alloy system

(b) $80 \mathrm{Au}-20 \mathrm{Pt}$ alloy system 

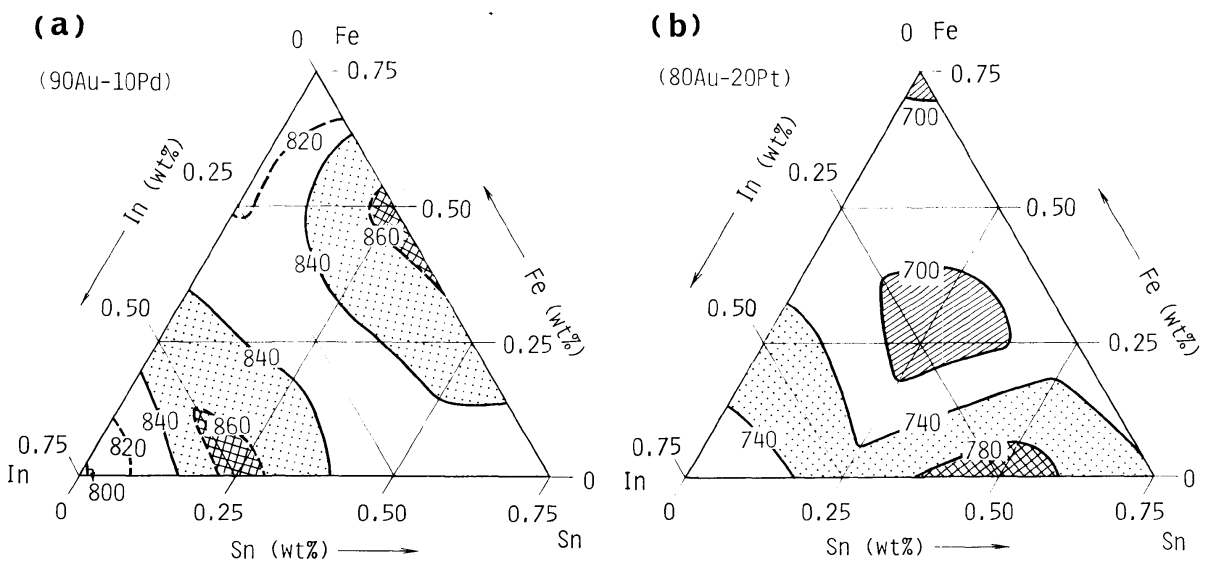

Figure 4 Equi-deflection-beginning temperature contours $\left({ }^{\circ} \mathrm{C}\right)$ drawn on the composition arrangement chart.

$\begin{array}{ll}\text { (a) } 90 \mathrm{Au}-10 \mathrm{Pd} \text { alloy system } & \text { (b) } 80 \mathrm{Au}-20 \mathrm{Pt} \text { alloy system }\end{array}$

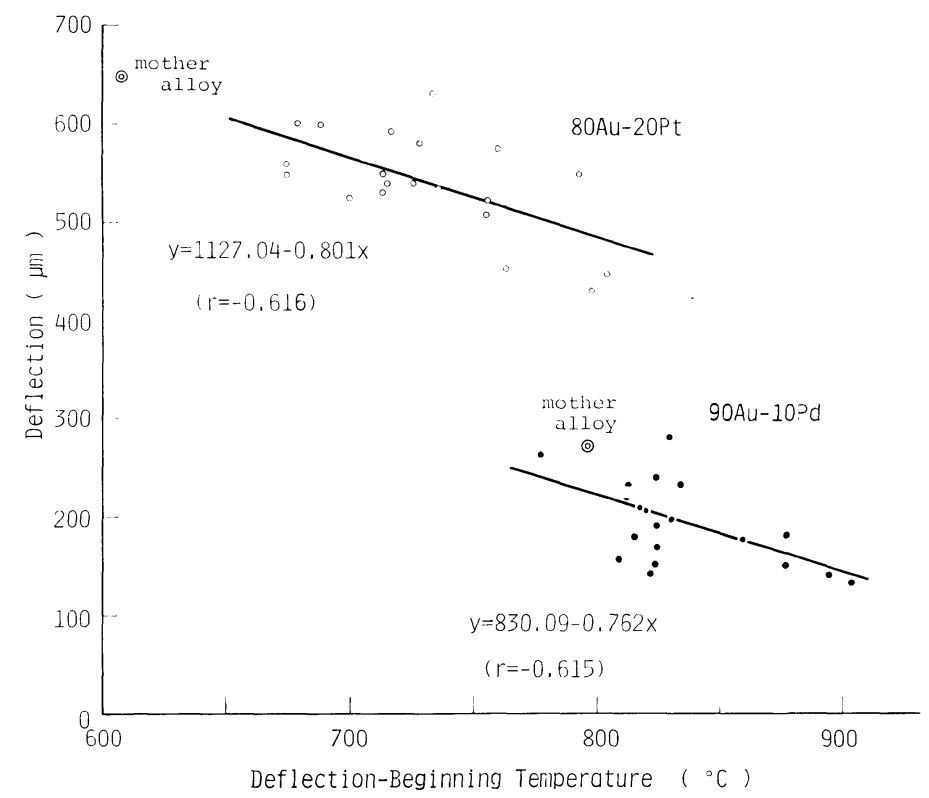

Figure 5 The relationship between the deflection-beginning temperature $(x)$ and the deflection (v).

Regression line: $\quad y=1127.04-0.801 \times(80 \mathrm{Au}-20 \mathrm{Pt}$ alloy system), $\mathrm{y}=830.09-0.762 \mathrm{x}(90 \mathrm{Au}-10 \mathrm{Pd}$ alloy system)

Correlation coefficient: $\quad-0.616(80 \mathrm{Au}-20 \mathrm{Pt}$ alloy system), -0.615 (90Au-10Pd alloy system)

at lower temperature. In 90Au-10Pd alloy system, the distribution ranges of both the deflection and the deflection-beginning temperature were smaller than those of the $80 \mathrm{Au}-$ 20Pt alloy system. 


\section{DISCUSSION}

The method to determine the deflection-beginning temperature was changed in this study. In the previous study, the linear portion of the deflection curve was extrapolated to its zero point, and the temperature corresponding to the extrapolated point was defined as the deflection-beginning temperature. The final value of the deflection curve on every chart paper ranged from 264 to $664 \mu \mathrm{m}$, so it was easy to find the linear portion for extrapolation to the zero point. In this case, the $90 \mathrm{Au}-10 \mathrm{Pd}$ alloy system showed a maximum value of $260 \mu \mathrm{m}$, so it was difficult to find a linear portion for extrapolation. Further, when the sensitivity of the detector amplifier was changed, the deflection-beginning temperature varied, indicating that the temperature can not be reliably determined. Therefore, another method had to be devised. The temperatures at which 10, 20, 30 and $40 \mu \mathrm{m}$ deflections occurred on the recorded chart papers were selected, and the usefulness and the reliability of the values were compared. The deflection of $10 \mu \mathrm{m}$ was too small to accurately obtain the temperature in some chart papers, and $40 \mu \mathrm{m}$ was too large for the chart papers that recorded small deflection. The temperature at which $20 \mu \mathrm{m}$ deflection was observed was the most reliable. Thus this temperature was defined as the deflectionbeginning temperature in this study, and the relation between the two definitions was examined. The corresponding values are plotted in Fig. 6. The correlation coefficient was 0.899 , indicating that the tendency of the concentration dependence of the deflectionbeginning temperature and the arrangement of the equi-deflection-beginning temperature contours discussed in the previous paper are unchangeable even if the values are replaced by those of the new definition.

The equi-deflection contours of both alloy systems show that the effect of the additional alloys is very complex. One of the ways to see the effect of each additional element is the one way analysis of variance in which the number of subjects per group varies. For example, No. 1 alloy contains $0.75 \% \mathrm{Fe}$, Nos. 2 and 3: $0.50 \% \mathrm{Fe}$, Nos. 4,5 and $6: 0.25 \%$,

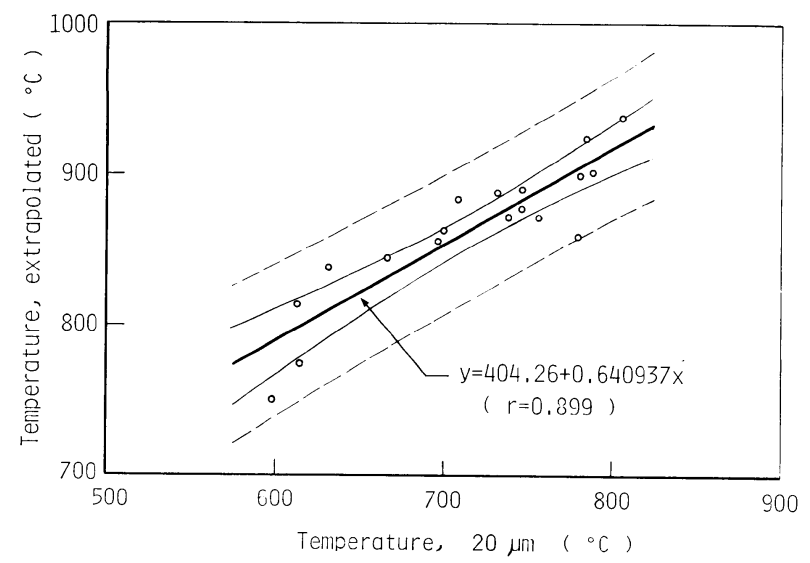

Figure 6 The relationship between the two methods of defining the deflectionbeginning temperature.

$\mathrm{x}$ : the temperature at which $20 \mu \mathrm{m}$ deflection occurs.

$y$ : the deflection derived by the extrapolation. 
and the rest contains no $\mathrm{Fe}$. If $\mathrm{Fe}$ content is used as the factor of the one way analysis of variance, the effect of $\mathrm{Fe}$ content can be evaluated. In this method, if the data are grouped according to Fe content, the effect of other elements is averaged. In the $80 \mathrm{Au}-$ $20 \mathrm{Pt}$ alloy system, the effect of $\mathrm{Sn}$ content became effective with $95 \%$ confidence. Other elements were not effective. In the 90Au-10Pd alloy system, no element was effective. In case of the deflection-beginning temperature, no element was effective in either system. Though the statistical analysis showed the ineffectiveness of the additional elements, the deflection ranged from 430 to $630 \mu \mathrm{m}$, for example, in the $80 \mathrm{Au}-20 \mathrm{Pt}$ alloy system. This means the combined effect of the additional elements is more important, than the effect of individual elements.

The values of the mother alloys due to the new definition are shown in both Figs. 2 and 5. The additional elements decreased the deflection and increased the deflectionbeginning temperature. This means that the additional elements decreased the possibility of a deformation of the castings during the firing procedure.

Kojima $^{10)}$ studied the effect of $\mathrm{Fe}$, In and $\mathrm{Sn}$ on the deflection at high temperatures by use of $85 \mathrm{Au}-5 \mathrm{Pt}-10 \mathrm{Pd}$ mother alloy. The result is shown in Fig. 7. The total amount of the additional elements was $1 \mathrm{wt} \%$, compared to $0.75 \mathrm{wt}^{\circ} \%$ in this study, but, there are some characteristic features to be noted. The composition of his mother alloy corresponds to that of No. 6 alloy in the previous study. The deflection at high temperatures in the previous study was $271 \mu \mathrm{m}$, and his result was $263 \mu \mathrm{m}$. Though the two experimental conditions were slightly different, almost equal values were obtained. By addition of $\mathrm{Fe}$, In and/or $\mathrm{Sn}$, the deflection decreased, and its values were distributed from 115 to $245 \mu \mathrm{m}$, mostly being less than $180 \mu \mathrm{m}$. The deflection of the 90Au-10Pd alloy in the previous study was $268 \mu \mathrm{m}$, and it decreased between 140 to $262 \mu \mathrm{m}$ by addition of Fe, In and/or Sn (Table 1). The effect of the additional elements in the ternary alloy

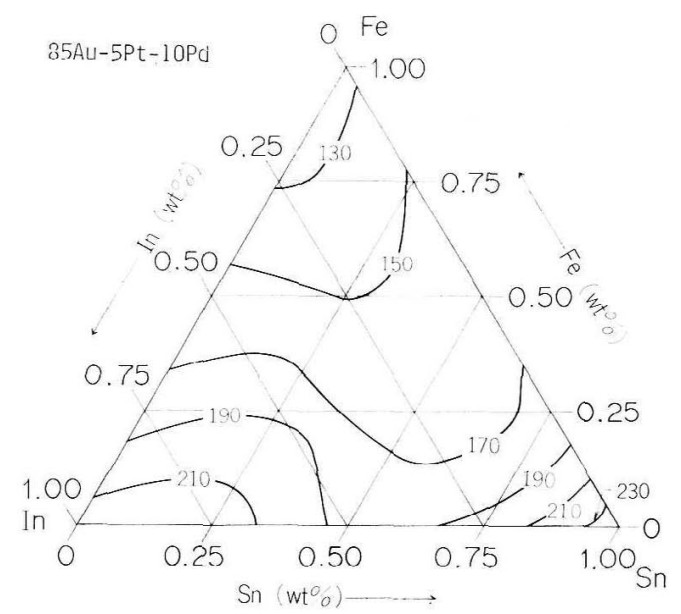

Figure 7 Equi-deflection contours $(\mu \mathrm{m})$ drawn on the composition arrangement chart (ref. 10). Total of $\mathrm{Fe}$, In and $\mathrm{Sn}$ is $1.0 \%$. Composition of mother alloy is $85 \mathrm{Au}-5 \mathrm{Pt}-10 \mathrm{Pd}$. 
system may be larger than that of the binary alloy system. The next point to be noted is that the arrangement of the equi-deflection contours is very different, not the mixture of the arrangements of $80 \mathrm{Au}-20 \mathrm{Pt}$ alloy and 90Au-10Pd alloy contours. Kojima ${ }^{10)}$ found that the deflection decreased toward the vertex of $\mathrm{Fe} 1 \%$, and increased toward In $1 \%$ and Sn 1\% vertexes. There are two maximum areas, contrary to the present result. Only common finding is that indium decreases the deflection to some extent, sometimes to the minimum value. The alloys that contain a large amount of indium show high values of the deflection. To further clarify the effect of the additional elements, it is necessary to examine the interaction between the components of the mother alloys and the additional elements, for example, solubility of the added elements, and precipitation of the phases. The effect of the elements on the mechanical properties is also important to understand the present results. The relation between the deflection and another properties would be discussed in the future paper.

\section{CONCLUSION}

Two alloys, 90Au-10Pd and $80 \mathrm{Au}-20 \mathrm{Pt}$, were used as the mother alloys, and iron, indium and/or tin were added to these alloys. The total amount of the additional elements was $0.75 \mathrm{wt} \%$. The deflection and the deflection-beginning temperature were measured.

The following results were obtained.

1. The deflection decreased by addition of Fe, In and/or Sn in both alloy systems. The amount of decrease was from 27 to $108 \mu \mathrm{m}$ in the 90Au-10Pd alloy system, and from 37 to $209 \mu \mathrm{m}$ in the $80 \mathrm{Au}-20 \mathrm{Pt}$ alloy system.

2. The deflection-beginning temperature increased by addition of $\mathrm{Fe}, \mathrm{In}$ and/or $\mathrm{Sn}$ in both alloy systems. The amount of increase was from 0 to $72^{\circ} \mathrm{C}$ in the $90 \mathrm{Au}-10 \mathrm{Pd}$ alloy system, and from 67 to $200^{\circ} \mathrm{C}$ in the $80 \mathrm{Au}-20 \mathrm{Pt}$ alloy system.

3. Both results showed that the mechanical properties at high temperatures were improved by addition of $\mathrm{Fe}$, In and/or Sn.

4. The deflection at high temperatures and the deflection-beginning temperature were negatively correlated. The alloy that showed larger deflection began to deflect at lower temperature.

5. Indium appears to increase the deflection in both alloy systems.

\section{REFERENCES}

1) Smith, B.B.: Considerations in the current use of porcelain to gold, Internat. Dent. J., 18: 280$287,1968$.

2) Tuccillo, J.J. and Nielsen, J.P.: Creep and sag properties of a porcelain-gold alloy, J. Dent. Res., 46: 579-583, 1967.

3) Moffa, J.P., Lugassy, A.A., Guckes, A.D. and Gettleman, L.: An evaluation of nonprecious alloys for use with porcelain veneers. Part 1 Physical properties, J. Prosthet. Dent., 30: 424-431, 1973.

4) Ando, N., Nakamura, K., Namiki, T., Sugata, T., Suzuki, T. and Moriyama, K.: Deformation of porcelain bonded gold alloys, J. Jpn. Soc. Dent. Appar. Mater., 13(28): 237-248, 1972. (in Japanese)

5) Ando, N.: Distortion of metal core for porcelain fusing and counter-measure, Practice in Pros- 
thodontics (Hotetsu Rinsho), 9: 305-312, 1977. (in Japanese)

6) Ando, N., Nakayama, M. and Nishikawa, Y.: Mechanism of distortion of precious alloy restoration at high temperatures. (Part 1) Deflection at high temperatures in Au-Pt-Pd alloy system, Dent. Mater. J., 3: 99-109, 1984. (in Japanese)

7) Iwama, H.: Bonding strength between porcelain and gold alloys (2) The effect of iron, indium and tin, J. Jpn. Soc. Dent. Appar. Mater., 17(37): 11-18, 1976. (in Japanese)

8) Nakayama, M., Ando, N. and Nishikawa, Y.: Effect of addition of Fe, In and Sn to the various properties of $88 \mathrm{Au}$ precious alloy for porcelain fusing (Part 1) Thermal expansion coefficient, $J$. J. Dent. Mat., 3: 13-25, 1984. (in Japanese)

9) Nakayama, M. and Ando, N.: Effect of addition of Fe, In and $\mathrm{Sn}$ to the various properties of $88 \mathrm{Au}$ precious alloy for porcelain fusing (Part 2) Thermal expansion hysteresis, J. J. Dent. Mat., 4: 716 723, 1985. (in Japanese)

10) Kojima, S.: Investigation of sag-resistance of precious alloys for porcelain fusing (Part 2) The effect of $\mathrm{Fe}, \mathrm{In}, \mathrm{Sn}$ addition on the distortion at high temperature of $85 \% \mathrm{Au}$ alloys for porcelain fusing, J. Jpn. Soc. Dent. Appar. Mater., 22(57): 29-36, 1981. (in Japanese) 
による上向き切削・研削および下向き切削・研削の仕上 面に及ぽす影響を調べた。本研究から次の結論が得られ た。

1）切削工具（カーバイドバー7664）によるマイクロ フィル型コンポジットレジンの切削仕上面は従来フイラ 一型コンポジットレジンに比べて著しく改善された。と れは分散相フイラーの粒径とそれに基くコンポジットレ ジンの不均質性によって切削抵抗とその変動が影響され るととを示唆する。

2) 研削工具 (ダイヤモンド工具 F 201 R) による研
削仕上面はカーバイドバーによるそれよりあ改善される と共に、コンポジットレジン間の差異が減少した。とれ は負のすくい角の増加によって切込みが減少したととに 起因すると考えられる。

3）両工具において，上向き切削・研削の仕上面の方 が下向き切削・研削のそれよりあ良くなった。とれは接 線切削・研削抵抗が上向き切削・研削では切削・研削予 定面の上方に働き，下向き切削・研削では逆に下方に働 くととから説明できる。

\section{光線重合レジンの細胞毒性（in vitro） 中村正明, 今井弘一, 大岛 浩, 工藤貴也, 吉岡宣史朗, 川原春幸 \\ 大阪霜科大学霜科理工学教室}

光線重合レジン 5 製品, すなわち, 可視光線重合タイ プ 4 製品, 紫外線重合タイプ 1 製品の硬化試料が HeLa S 3 細胞に対しておよぼす影響を調へるために, in vitro 環境下で細胞コロニー形成法を駆使して実験を行った。 2 週間の単位浸漬期間を合計 6 週間にわたって, 従来か ら行っている口腔内の動的環境のシミュレーションを目 ざした旋回投入浸漬を続け，各時期の浸漬液を実験に用 いた。テストした各材料で初期に浸漬液の渾度があがる と中等度から強い細胞毒性を示した。しかし，その後は
紐胞毒性は急速に消失し去った。この結果は同時にテス トした従来型のクリアフィル F と似ていたし, 以前に テストした MFR タイプなどを含む従来型製品とむ軌 を一にするすのであった。以上の実験結果はテストした 2 種類の光線重合レジンが細胞に対して従来型製品とき わめてよく似た影響を及ぽすてとを示している。

本研究の一部は文部省科学研究費補助の試験研究 (56870103) による。

貴金属修復物の高温に括ける变形機構

（第 2 報）高温たわみに対する鉄、インジウム，スズ添加の影響

\section{安藤進夫，中山正彦}

日本㐘科大学理工学教室

鉄,インジウムおよび/あるいは, スズを 2 種の母合 金, $90 \mathrm{Au}-10 \mathrm{Pd}, 80 \mathrm{Au}-20 \mathrm{Pt}$ ，に添加し，各母合金に つき10種の合金を試作した。添加元素の合計は，0.75\% であった。高温たわみ（試験片を 1050 ○まで加熱した後 の最終たわみ量) および, 変形開始温度 (20 $\mu \mathrm{m}$ のたわ みを生じる温度）を測定し，てれらの性質に対する添加 元素の影響を調べた。
鉄，インジゥム，スズの添加により，いずれの合金系 においても, 高温たわみは減少し, 変形關始温度は增大 した。これらの結果は, 鉄, インジウム, スズの添加に より, 高温における機械的性質が改善された事を証明し ている。高温たわみと変形開始温度の間には, 負の相関 関係がみられた。インジウムはいずれの合金系において も，高温たわみを增大させる椂である。 